\title{
EVALUATION OF SPEEDING AND BEHAVIOUR OF DRIVERS IN ROADWORK ZONES
}

\section{DONATAS ČYGAS', DOVYDAS SKRODENIS²*, AIVARAS PAŠKAUSKAS ${ }^{3}$, ŽIVILE் SUŠINSKAITE் ${ }^{4}$, LAURA ŽALIMIENE் ${ }^{1,3,4}$ Dept of Roads, Vilnius Gediminas Technical University, Vilnius, Lithuania ${ }^{2,5}$ Road Research Institute, Vilnius Gediminas Technical University, Vilnius, Lithuania}

Received 9 August 2017; accepted 23 August 2018

\begin{abstract}
Due to the increased traffic flow, more and more roadwork zones are formed in highways. Accidents are a significant problem in all European countries in roadwork zones while noncompliance with speed limits is one of the major safety concerns. Therefore roadwork zones are critical places from the point of traffic safety view where the possibility to get into an accident is increased. Roadwork zones introduce deviations from regular travel situations, and appropriate speed is needed to assure that the driver navigates safely through the roadwork zone. This research focuses on speed measurement in roadwork zones and attempts to evaluate the effectiveness of safety measures on speed limit compliance.
\end{abstract}

Keywords: enforcement, roadwork zone, safety measures, speeding.

\section{Introduction}

Continually rising traffic volume causes the degradation of the road and shorter inter-repair period. Therefore, the number of roadwork zones is continuously increasing. Road operation and maintenance are

\footnotetext{
* Corresponding author. E-mail: dovydas.skrodenis@vgtu.lt 
the central part of road asset management. Only cost-efficient and timely repair of degraded pavements ensure optimal and balanced use of funds allocated to road maintenance, as well as cost savings for the society. However, it should be noted that any intervention into the lane, where roadwork is carried out without closing of traffic, causes discomfort to the road users. Overcoming the roadwork zone on the road increases the likelihood of accidents. A roadwork zone entails deviations from regular travel in a discrete road section and may include angular deviations from the regular road design. Without proper control of the vehicle, a driver may collide with other vehicles, run off the road, or even enter the restricted areas of the roadwork zone (Vadeby, Sörensen, Bolling, Cocu, Saleh, Aleksa, ... \& Tucka, 2016).

Human errors and excessive speed have been identified as the significant causes of roadwork zone crashes (Debnath, Blackman, \& Haworth, 2012). Human errors are attributed to poor behaviour in certain situations (driving through a red traffic light signal), driver inattention (poor attention to road signs). Also, there are much more surroundings in roadwork zones whose easily distract the driver. Drivers used to underestimate the danger of roadwork zone since that not all risks and hazards can be controlled entirely. Debnath, Blackman, \& Haworth (2015), Thomson, Saleh, La, Cocu, \& Tucka (2014), Atombo, $\mathrm{Wu}$, Zhong, \& Zhang (2016) and Soole, Watson, \& Fleiter (2013) and SWOV (2010) report state that speeding is a most common violation and accidents causer in roadwork zones.

\section{Literature Review}

Khattak, Khattak \& Council (2002) and a study of the European Transport Safety Council (2011) indicate that driving through the roadwork zone significantly increases the chances to get into an accident. Paying attention to the safety of road workers is necessary. In 2009, in Netherlands 18 people were killed in roadwork zones (SWOV, 2010). In 2010, in Austria 120 road accidents occurred in roadwork zones where four people were killed (European Transport Safety Council, 2011). In 2012, Sweden reported about 385 accidents in roadwork zones where three people were killed (Liljegren, 2014). In 2014, in Pennsylvania State (USA) 24 people were killed at road construction sites, 9 of them - road workers (Occupational Fatal Injuries in 2014). In 2011, in Poland 11 accidents occurred in roadwork zones where 18 people were killed (Żochowska, 2014). Implementing innovative measures, running educational campaigns, coaching road workers on the behaviour of the roadwork zones can be useful tools to prevent accidents at roadwork zones. 
Adminaitè, Allsop, \& Jost (2015) indicates that accidents in roadwork zones account for $4 \%$ of all accidents occurring on motorways in Austria and $9 \%$ in Belgium. Also, Lithuania has taken action to reduce the number of accidents in roadwork zones, although they account for less than $1 \%$ of the total number of road accidents in the period 2012-2015.

One of the main problem causing accidents in roadwork zones is that drivers often accepts roadwork zone as a standard section of road where there are none speed and traffic restrictions. For this reason, various elements and measures of traffic calming should be used to prevent the occurrence of a road accident. Worldwide wide varieties of safety measures are used to improve speed limit compliance. These measures are be categorised based on their functional characteristics as informational, physical, enforcement, and educational (Debnath, Blackman, \& Haworth, 2012). The informational measures procure road users to roadwork related information such as speed limits or hazard warnings. Research by Brewer, Pesti, \& Schneider (2005) has shown that the presence of portable changeable message signs reduced the average speed by $3.4 \mathrm{~km}$ for passenger cars and $2.1 \mathrm{~km} / \mathrm{h}$ for trucks in Texas roadwork zones. Georgia Transportation Institute (Wang, Dixon, \& Jared, 2005) determined that the variable message sign with radar do help reduce the adjacent speed at two-lane and two-way rural highway locations. Though the speed reduction is small (ranging from $1.6 \mathrm{~km} / \mathrm{h}$ to $4.8 \mathrm{~km} / \mathrm{h}$ ) the reduction is maintained over time as well as downstream of the sign placement. Clemson Researchers, in their study (Sarasua, Ogle, Davis, \& Chowdhury, 2006) determined that the use of variable message signs reduce the average speed by $6.4 \mathrm{~km} / \mathrm{h}$.

Various physical measures are used at roadwork zones and usually they are placed on the road surface with the aim to reduce speed. The California Dept of Transportation (in 2012) tested rumble strips in areas leading up to roadwork zones and found that $46 \%$ of traffic slowed down, with nearly half of all vehicles slowing down by an average speed of $12.8 \mathrm{~km} / \mathrm{h}$. Other studies report less speed reduction of $1.8-3.5 \mathrm{~km} / \mathrm{h}$ for cars (Fontaine \& Carlson, 2001) and 1.5-3.7 km/h for trucks (Meyer, 2000). Some countries are applying techniques of temporary lane narrowing. However, some studies determined that too narrow lanes (less than $3.0 \mathrm{~m}$ ) may lead to driver discomfort, difficulty in remaining within the lane and increased collisions (Harmelink \& Edwards, 2005).

Enforcement measures are used to impose speed limits by the presence of police car or automated speed monitoring. The Minnesota Dept of Transportation (Minnesota DOT, 1999) examined the effectiveness of police enforcement in roadwork zones during 1999. The study found that the 85 th percentile speed was reduced from $82.0 \mathrm{~km} / \mathrm{h}$ to $69.2 \mathrm{~km} / \mathrm{h}$ when a police vehicle was parked upstream of the work
Živilè Sušinskaitè,

Laura Žalimienè

Evaluation

of Speeding

and Behaviour

of Drivers

in Roadwork Zones 
zone (Minnesota DOT, 1999). In 2007, the Oregon Dept of Transportation evaluated an initial photo radar installation in a highway roadwork zone (Joerger, 2010). Photo radar enforcement had a substantial impact on reducing the number of speeding vehicles in a construction roadwork zone. An average of speeding reduced by approximately $24 \%$.

Educational measures are used to improve awareness of road users of the risks at roadwork zones through public campaigns and training programs (Debnath, Blackman, \& Haworth, 2012). However, their actual effectiveness regarding speed reduction in a roadwork zone could not be determined due mainly to the lack of objective and reliable evaluations (Debnath, Blackman, \& Haworth, 2015).

\section{Data collection and results}

\subsection{Experimental place and apparatus}

Classifiers of traffic data were installed in pursuance to determine vehicles speed in roadwork zones. Devices were set up to indicate the speed and length of passing vehicles (Figure 1). The high-performance traffic data classifier for two-lane or direction roads (SDR traffic collector) was chosen due to the accuracy and appearance. This collector does not attract drivers and results of the traffic flow speed are genuine. Vehicles were classified into five categories:

- powered two-wheelers (motorcycles);

- passenger cars;

- single unit 2-axle trucks;

- single unit 3-axle or 4-axle trucks;

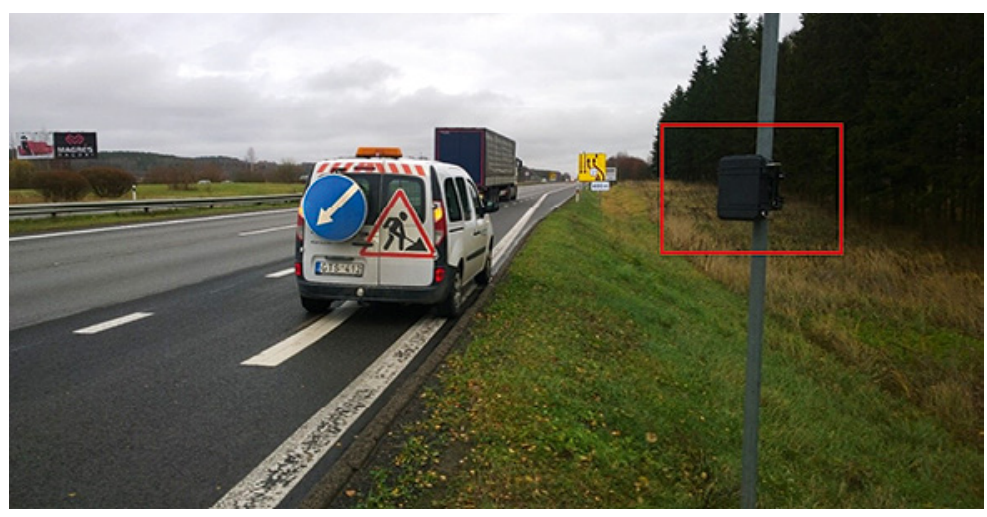

Figure 1. Traffic data collection device 


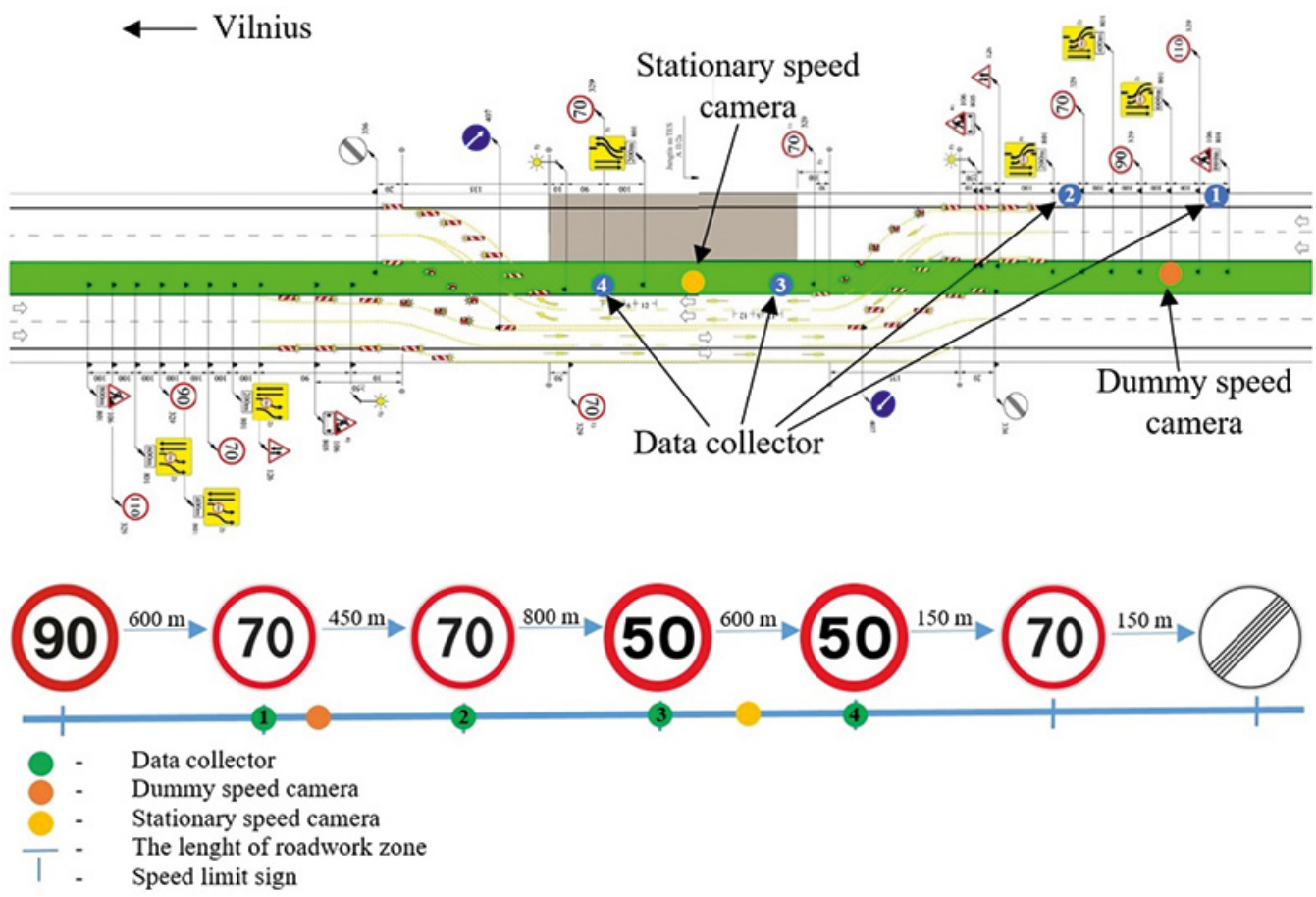

Figure 2. The scheme of speed measuring in a roadwork zone

- $\quad$ single unit 5 or more axle trucks.

The analysis of roadwork zones in highways, national and regional roads indicated a tendency to exceed speed limits on highways. Meanwhile, apart from isolated cases, there is no tendency to exceed speed limits in roadwork zones in national and regional roads. Therefore, the speed measurement research carried out in highway A1 Vilnius-Kaunas-Klaipèda, section $60.80-63.30 \mathrm{~km}$, on August 10-22, 2016. Four traffic data collectors that were installed in the roadwork zone are listed in Figure 2.

\subsection{Experimental results}

The positions of data collectors chosen to determine what influence to speeding have stationary speed camera and dummy speed camera. Temporary lanes narrowed because let moving vehicles in two lanes per one direction. The first lane was $2.60 \mathrm{~m}$ in width, while the second was $2.00 \mathrm{~m}$. Installed collectors gathered data for 12 days. Figure 3 shows the dependence of the speed on the vehicle category.

Speed results showed that all types of vehicles violated the speed rules within the roadwork zone. By speed results, the average speed of 
passenger cars and single unit 3-axle or 4-axle trucks was highest. The first data collector recorded that the average speed of motorcycles was highest at the beginning of the approach roadwork zone but gradually decreased towards to work zone. Transition zone was between second and third data collectors. The average speed of all vehicle categories was much lower in this zone due to the nearby roadwork area and narrow lanes. Since motorcycles are the most vulnerable road users, their average speed was the lowest in this section of the roadwork zone. However, the average speed was higher than the allowable speed limit nevertheless what vehicle category during the roadwork zone. The fourth data collector stated increasing of average speed, and the fact of roadwork zone ending possibly influence these speed violations. The particular roadwork area was passed. For this reason, road users did not see the danger to driver faster. The average speed could be higher, but the stationary speed camera was installed in the middle of the roadwork zone, between third and fourth data collectors, which impeded offenders.

Figure 4 shows the average value of speeding and which data collector recorded most violations of speeding. First and second data collectors installed in the approach roadwork zone to determine the dummy speed camera and warning signs efficiency. Third and fourth data collectors were placed to fix what influence has a stationary speed camera to speed. It is possible to determine how road users deal with transition area and narrowed temporary passing lanes from driving speed perspective having all results.

Analysis showed that dummy speed camera in the approach roadwork zone reduced the number of speed offenders by $17 \%$ who were

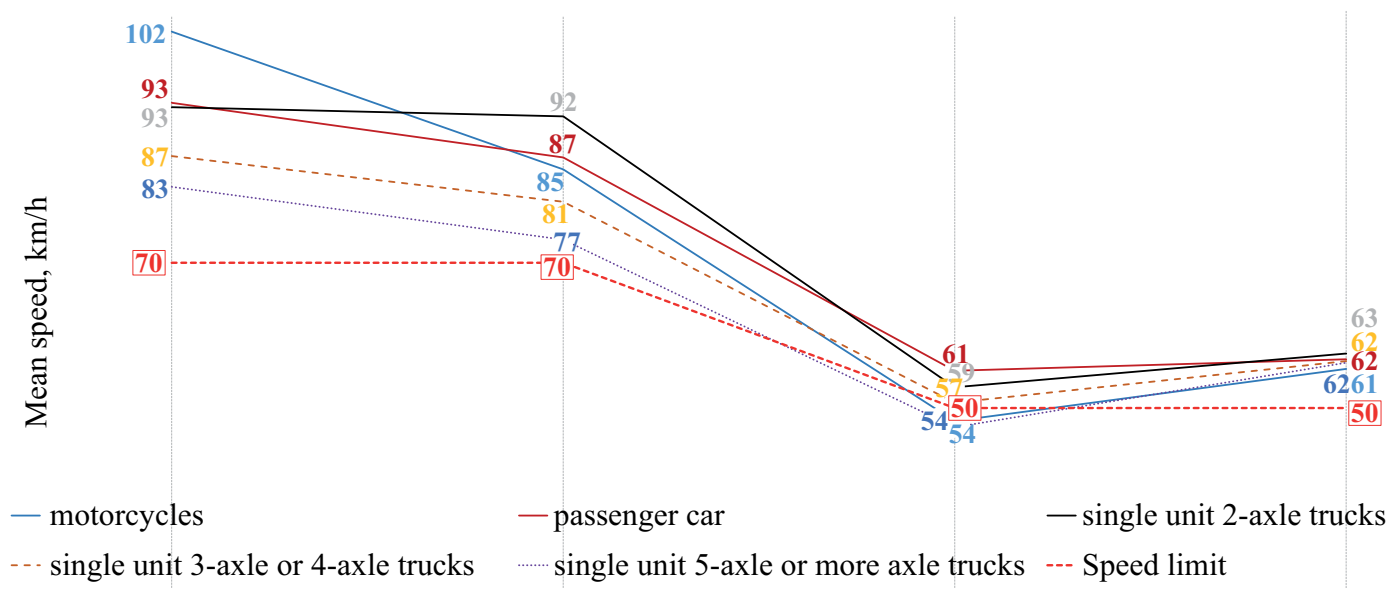

Figure 3. Speed distribution according to vehicle category 
speeding more than $20 \mathrm{~km} / \mathrm{h}$. Second data collector recorded $7 \%$ fewer speed violations, while comparing to the first data collector. The average speeding reduced by $2 \mathrm{~km} / \mathrm{h}$ (from $19 \mathrm{~km} / \mathrm{h}$ to $17 \mathrm{~km} / \mathrm{h}$ ). However, looking at the results of the second data collector, it is a visible increase of up to $20 \mathrm{~km} / \mathrm{h}$ speeding violations. It is concluded that dummy camera reduced the number of high-speed violations (over $20 \mathrm{~km} / \mathrm{h}$ ) but increased the number of low-speed (up to $10 \mathrm{~km} / \mathrm{h}-8 \%$ ) and mediumspeed (11-20 km/h - 2\%) violations. Enforcement camera systems... (2008), dummy speed camera influences speeding, but temporary measurement and efficiency decreases during the time.

Results from second and third data collectors determined that the high-speed violations decrease by $18 \%$ (to 13\%). The total amount of violations decreased by $10 \%$ in this section of roadwork zone, and the average speeding decreased to $16 \mathrm{~km} / \mathrm{h}$. It can be assumed that transition area, narrow lanes, and warning signs could influence to speed decrease.

Results from third and fourth data collectors showed that the total amount of speeding violations decreased by $5 \%$ and low-speed violations down by $8 \%$. However, the fourth data collector recorded $5 \%$ more medium-speed violations.

Result analysis of first and fourth data collectors indicates that the average speeding decreased by $3 \mathrm{~km} / \mathrm{h}$. The number of violations decreased by $22 \%$ (from $96 \%$ to $74 \%$ ). The number of high-speed offenders decreased by $37 \%$. However, the medium-speed and low-speed offenders increased respectively by $9 \%$ and $6 \%$. A frequency of speeding

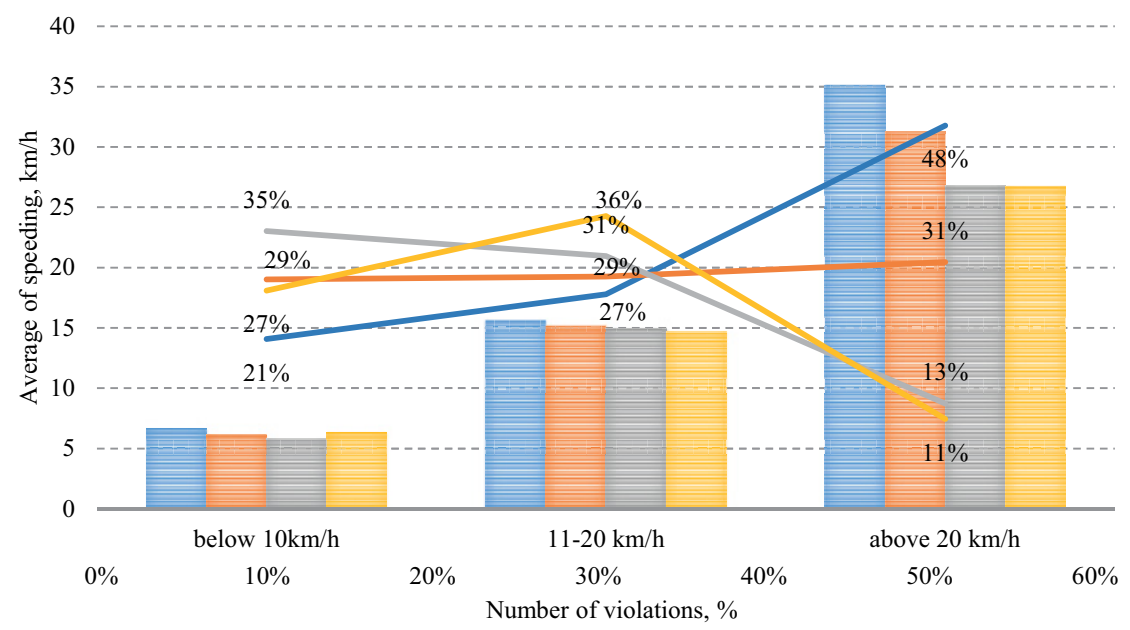

E First data collector speed limit $70 \mathrm{~km} / \mathrm{h} \quad$ = Second data collector speed limit $70 \mathrm{~km} / \mathrm{h}$

Third data collector speed limit $50 \mathrm{~km} / \mathrm{h} \quad \square$ Fourth data collector speed limit $50 \mathrm{~km} / \mathrm{h}$

Figure 4. Speed distribution in a roadwork zone
Živilè Sušinskaitè,

Laura Žalimienè

Evaluation

of Speeding

and Behaviour

of Drivers

in Roadwork Zones 
up to $10 \mathrm{~km} / \mathrm{h}$ can be influenced by the valid Lithuanian legal acts, which make no provision for the financial responsibility of the violator of Road Traffic Rules but an only warning.

\subsection{Drivers behaviour in roadwork zones}

The enclosure scheme and traffic calming measures have much influence on the behaviour of drivers in roadwork zone. For this reason, the evaluation of roadwork zone installation and correspondence to sample schemes in regulations was involved in this research part. Nineteen roadwork zones were selected for scheme and inspection of the behaviour of drivers. The Table presents the list of selected roadwork zones for research.

Road administrations and agencies worldwide provide standards and guidelines for the design and implementation of traffic calming measures of roadwork zones. These documents must be followed to ensure the safety of motorists and workers. Typically, these documents require traffic control devices such as temporary speed limits, signs, barricades, and other devices placed in advance of and within the roadwork zone. They are used to inform, warn, and guide drivers and help them to maintain proper positioning and speed(Paolo \& Sar, 2012). In all cases, the roadwork zone enclosure and organization carried out by the standard schemes, which are available on the T DVAER 12 Enclosure and Traffic Regulatory Rules in Road Work Zone (2012). Additional signs adjusted some schemes with other permissible speed limits (lower permissible speed).

T DVAER 12 (2012) regulation states that are not required to revoke the former horizontal markings (white colour). As a result, the horizontal marking with a white colour was left in all investigated cases, and temporary lanes were marked with a yellow colour. In several study sites, different marking options were misleading drivers on the carriageway and led to chaotic driving. Although, during the investigation, none of the road accidents was recorded. Double marking is misleading drivers and increases the risk of accidents (SWOV, 2010).

Oncoming traffic flow in roadwork zones separated by plastic barriers, connected to each other to form a solid line. There have been instances when the oncoming traffic flow separated only by directional guidelines without reflective or light-emitting elements. This type of enclosure does not protect against intrusion of the vehicle into the lane of the oncoming traffic flow, which can cause painful accidents.

The carriageway and constructed lane separated by steep slope without any elements, which can physically stop departing vehicle. What is more, lack of light-emitting elements, whose should be an aid in the dark by marking the side of the carriageway? The accident 
Table. Selected roadwork zones for installation

and inspection of the behaviour of drivers

\section{No. Road, section from-to $\mathrm{km}$}

A1 Vilnius-Kaunas-Klaipèda

$19.75-22.00 \mathrm{~km}$

2.

A1 Vilnius-Kaunas-Klaipèda 60.80-63.30 km (right side)

3.

A2 Vilnius-Panevėžys

$71.60-72.80 \mathrm{~km}$

4. A3 Vilnius-Minskas

$12.10-12.30 \mathrm{~km}$

5. A5 Kaunas-Marijampolè-Suvalkai
17.34-23.40 km (right side)

\begin{tabular}{|c|c|c|}
\hline 6. & $\begin{array}{l}\text { A6 Kaunas-Zarasai-Daugpilis } \\
142.00-150.10 \mathrm{~km}\end{array}$ & $\begin{array}{l}\text { Road rehabilitation. One lane, traffic controlled by } \\
\text { traffic lights. }\end{array}$ \\
\hline 7. & $\begin{array}{l}\text { A8 Panevėžys-Aristava-Sitkūnai } \\
8.32-23.36 \mathrm{~km}\end{array}$ & $\begin{array}{l}\text { Road rehabilitation. Speed reduced limit } 70 \mathrm{~km} / \mathrm{h} \text {, } \\
\text { two lanes ( } 1 \text { lane for each direction). }\end{array}$ \\
\hline 8. & $\begin{array}{l}\text { A15 Vilnius-Lyda } \\
11.58-12.59 \mathrm{~km}\end{array}$ & $\begin{array}{l}\text { Road maintenance. Narrowed lanes, reduced speed } \\
\text { limit, two lanes ( } 1 \text { lane for each direction). }\end{array}$ \\
\hline 9. & $\begin{array}{l}\text { A15 Vilnius-Lyda } \\
12.59-12.60 \mathrm{~km}\end{array}$ & $\begin{array}{l}\text { Bridge construction. A temporary detour has built, } \\
\text { traffic controlled by traffic lights. }\end{array}$ \\
\hline 10. & $\begin{array}{l}\text { A15 Vilnius-Lyda } \\
15.63-15.73 \mathrm{~km}\end{array}$ & $\begin{array}{l}\text { Bridge construction. A temporary detour has built, } \\
\text { traffic controlled by traffic lights. }\end{array}$ \\
\hline 11. & $\begin{array}{l}102 \text { Vilnius-Švenčionys-Zarasai } \\
16.30-21.82 \mathrm{~km}\end{array}$ & Speed limit $50 \mathrm{~km} / \mathrm{h}$. \\
\hline 12. & $\begin{array}{l}108 \text { Vievis-Maišiagala-Nemenčinè } \\
53.00-53.66 \mathrm{~km}\end{array}$ & Speed limit 30 km/h. \\
\hline 13. & $\begin{array}{l}129 \text { Antakalnis-Jieznas-Alytus-Merkinè } \\
27.18-27.60 \mathrm{~km}\end{array}$ & $\begin{array}{l}\text { Speed limit } 50 \mathrm{~km} / \mathrm{h} \text {, traffic controlled by traffic } \\
\text { lights. }\end{array}$ \\
\hline
\end{tabular}

Interchange construction. The traffic redirected from the right side of the road to the left side. Oncoming traffic, for this reason, speed limit $50 \mathrm{~km} / \mathrm{h}$. Four lanes (2 lanes for one direction). Interchange construction. The traffic redirected from the right side of the road to the left side. Oncoming traffic, for this reason, speed limit to $50 \mathrm{~km} / \mathrm{h}$. Four lanes (2 lanes for one direction).

Pedestrian overpass construction. The traffic redirected from the right side of the road to left. Oncoming traffic, speed limit $70 \mathrm{~km} / \mathrm{h}$. Two lanes (1 lane for each direction).

Pedestrian overpass construction. No oncoming traffic, no speed reduction. Four lanes (2 lanes for one direction).

Road rehabilitation. Traffic redirected from the right side of the road to left. Oncoming traffic, speed limit $70 \mathrm{~km} / \mathrm{h}$. Two lanes (1 lane for each direction).

Road rehabilitation. One lane, traffic controlled by traffic lights.

Road rehabilitation. Speed reduced limit $70 \mathrm{~km} / \mathrm{h}$ Road maintenance. Narrowed lanes, reduced speed 


\begin{tabular}{|c|c|c|}
\hline No. & $\begin{array}{l}\text { Road, } \\
\text { section from-to km }\end{array}$ & Notes \\
\hline 14. & $\begin{array}{l}141 \text { Kaunas-Jurbarkas-Šilutè-Klaipèda } \\
18.7-19.4 \mathrm{~km} \\
20.6-21.54 \mathrm{~km}\end{array}$ & $\begin{array}{l}\text { Speed limit } 50 \mathrm{~km} / \mathrm{h} \text {, traffic controlled by traffic } \\
\text { lights. }\end{array}$ \\
\hline 15. & $\begin{array}{l}183 \text { Azžuolų Būda-Kazlų Rūda } \\
0.00-4.37 \text { km }\end{array}$ & Speed limit $50 \mathrm{~km} / \mathrm{h}$. \\
\hline 16. & $\begin{array}{l}2606 \text { Gudeliai-Smilgiai-Būdviečiai } \\
2.00-3.00 \mathrm{~km}\end{array}$ & Speed limit $50 \mathrm{~km} / \mathrm{h}$. \\
\hline 17. & $\begin{array}{l}2813 \text { Gečiai-Kuktiškės-Tauragnai } \\
0.00-7.13 \mathrm{~km}\end{array}$ & $\begin{array}{l}\text { Narrowed lanes, speed limit } 30 \mathrm{~km} / \mathrm{h} \text {, traffic } \\
\text { controlled by traffic lights. }\end{array}$ \\
\hline 18. & $\begin{array}{l}3311 \text { Jieznas-Nibriai } \\
0.00-7.53 \mathrm{~km}\end{array}$ & Speed limit $50 \mathrm{~km} / \mathrm{h}$. \\
\hline 19. & $\begin{array}{l}\text { 4727 Trakai-Lentvaris-Mūrinè Vokè } \\
3.77-5.30 \mathrm{~km}\end{array}$ & Narrowed lanes, speed limit 50 km/h. \\
\hline
\end{tabular}

analysis showed that one of the most frequent causes of accidents in the roadwork area is driving off the road. Contractors should select the appropriate measures to ensure that the vehicle will not be able to leave the lane and drive off the road or crash into an oncoming vehicle.

Traffic lights used to regulate traffic flow in a few roadwork zones, since there was no opportunity to let traffic flow in two lanes. The high traffic volume caused the jams in the roadwork zone. It is essential to estimate traffic volume and composition to adjust the light cycle of a red and green traffic light. The poor timing of traffic light could cause additional problems when drivers start running on a red light when they did not see any oncoming vehicle in front. In addition, it should be considered the length of the road sections controlled by a traffic light.

Another common phenomenon in roadwork zones, especially in highways, was short-term narrow lanes. By T DVAER 12, the minimum width of lanes shall be $2.50 \mathrm{~m}$, but in exceptional cases, it may be reduced to $2.20 \mathrm{~m}$. From a human factors perspective, reduced lane width means less lateral maneuvering distance and a reduction in the distance between the vehicle and roadside obstacles such as traffic control drums or barriers. These measures require more driver attention, and drivers often compensate by reducing speeds (Harmelink \& Edwards, 2005). During the investigation, it was noted that vehicles hardly contain in lanes, which can be a cause of damage-only accidents. The traffic flow was organized in two lanes in each direction, and heavy vehicles consisted of more than $10 \%$ of traffic volume. It was not practically possible to overtake the heavy vehicle. By Li \& Bai (2009) studies, a road accident with a heavy vehicle 
is four times more dangerous than a road accident with a car. Therefore, instead of two lanes in each direction, it became one wide lane for safe overtaking because the second short-term lane was too narrow.

\section{Conclusions}

Experimental results showed that violation of the speed limit on the roadwork zones is a common phenomenon. Passive traffic calming measures, including speed limit signs, cones, and road marking, maintain the order of driving and helps to predict the behaviour of road users. However, these measures do not ensure that drivers comply with the permissible speed. Research results showed that the use of traffic calming measures, including stationary speed camera or dummy speed camera, help to maintain the permissible speed limit. The presence of the dummy speed camera in roadwork zone reduced high-speed violations by $17 \%$. Stationary speed camera reduced total speeding violations by $5 \%$. However, the presence of measure not only reduced the number of violations but also guaranteed the sustainability of high-speed violations. The complex of active (dummy speed camera and stationary speed camera) and passive (speed limit signs, cones, road marking) traffic calming measures reduced the average speeding by $3 \mathrm{~km} / \mathrm{h}$. The number of all violations from the approach to the end of the roadwork zone decreased by $22 \%$, and the number of high-speed offenders decreased by $37 \%$.

Visual inspection of roadwork zones and analysis of the behaviour of drivers showed that contractors do not always follow the rules of regulations and does not take care of traffic organization through the roadwork zone. The speed was not recorded in many roadwork zones, but it was clear that many road users exceeded the permitted speed. Traffic calming measures and selected traffic organization scheme determine the misbehaviour of road users. Permanent road marking should be erased or hidden to avoid the distraction of road users. Oncoming traffic flow should be separated by solid elements whose could stop the deviated motor vehicle. The road section where traffic light applied for traffic organization may be simulated with computer software by traffic flow and the share of heavy vehicles. This step allows selecting proper time loops of a traffic light to prevent traffic jams and indignation of road users. Narrowed lanes could be helpful to reduce speeding in roadwork zones, but it cannot be used in all roadwork situations.

\section{Acknowledgements}

The Lithuanian Road Administration under the Ministry of Transport and Communications of the Republic of Lithuania has funded the research. 


\section{REFERENCES}

Adminaitè, D., Allsop, R., \& Jost, G. (2015, May). Ranking EU Progress on Improving Safety Motorway. PIN Flash Report 28, European Transport Safety Council. $32 \mathrm{p}$.

Atombo, C., Wu, C., Zhong, M., \& Zhang, H. (2016). Investigating the motivational factors influencing drivers intentions to unsafe driving behaviours: Speeding and overtaking violations. Transportation research part F: traffic psychology and behaviour, 43, 104-121.

https://doi.org/10.1016/j.trf.2016.09.029

Brewer, M. A., Pesti, G., \& Schneider, W. H. (2005). Identification and testing of measures to improve work zone speed limit compliance (No. FHWA/ TX-06/0-4707-1). Texas Transportation Institute, Texas A \& M University System.

Debnath, A. K., Blackman, R. A., \& Haworth, N. L. (2012). A review of the effectiveness of speed control measures in roadwork zones.

Debnath, A. K., Blackman, R., \& Haworth, N. (2015). Common hazards and their mitigating measures in work zones: A qualitative study of worker perceptions. Safety science, 72, 293-301. https://doi.org/10.1016/j.ssci.2014.09.022

Speed Enforcement Camera Systems Operational Guidelines, Federal Highway Administration, National Highway Traffic Safety Administration. 2008.

European Transport Safety Council (ETSC) (2011, May). "PRAISE": Preventing Road Accidents and Injuries for the Safety of Employees. $42 \mathrm{p}$.

Fatal occupational injuries at road construction sites, 2003-2014

Fontaine, M., \& Carlson, P. (2001). Evaluation of speed displays and rumble strips at rural-maintenance work zones. Transportation Research Record: Journal of the Transportation Research Board, (1745), 27-38. https://doi.org/10.3141/1745-04

Harmelink, M. D., \& Edwards, R. (2005). Synthesis of Practices for Work Zone Speed Management.

Joerger, M. D. (2010). Photo radar speed enforcement in a state highway work zone: demonstration project Yeon Avenue (No. OR-RD-10-17). Oregon. Dept. of Transportation. Research Section.

Khattak, A. J., Khattak, A. J., \& Council, F. M. (2002). Effects of work zone presence on injury and non-injury crashes. Accident Analysis \& Prevention, 34(1), 19-29. https://doi.org/10.1016/S0001-4575(00)00099-3

Li, Y., \& Bai, Y. (2009). Highway work zone risk factors and their impact on crash severity. Journal of Transportation engineering, 135(10), 694-701. https://doi.org/10.1061/(ASCE)TE.1943-5436.0000055

Liljegren, E. (2014, April). Traffic accidents in connection to road work in Sweden. In Transport Research Arena (TRA) 5th Conference: Transport Solutions from Research to Deployment European Commission Conference of European Directors of Roads (CEDR) European Road Transport Research Advisory Council (ERTRAC) WATERBORNE ${ }^{\text {TP }}$ European Rail Research Advisory Council (ERRAC) Institut Francais des Sciences et Technologies 
des Transports, de l'Aménagement et des Réseaux (IFSTTAR) Ministère de l'Écologie, du Développement Durable et de l’Énergie.

Meyer, E. (2000). Evaluation of orange removable rumble strips for highway work zones. Transportation Research Record: Journal of the Transportation Research Board, (1715), 36-42. https://doi.org/10.3141/1715-06

Minnesota Department of Transportation (Minnesota DOT) (1999). Effectiveness of Law Enforcement in Reducing Vehicle Speeds in Work Zones. St. Paul, Minnesota.

Paolo, P., \& Sar, D. (2012). Driving speed behaviour approaching road work zones on two-lane rural roads. Procedia-Social and Behavioral Sciences, 53, 672-681. https://doi.org/10.1016/j.sbspro.2012.09.917

Sarasua, W. A., Ogle, J. H., Davis, W. J., \& Chowdhury, M. A. (2006). Better Management of Speed Control in Work Zones (No. FHWA-SC-06-10).

Soole, D. W., Watson, B. C., \& Fleiter, J. J. (2013). Effects of average speed enforcement on speed compliance and crashes: A review of the literature. Accident Analysis \& Prevention, 54, 46-56. https://doi.org/10.1016/j.aap.2013.01.018

SWOV Institute for Road Safety Reaseach (2010, July). Fact sheet. Roadworks and road safety.

T DVAER 12 (2012). Automobilių keliu darbo vietu aptvérimo ir eismo reguliavimo taisykless.

Thomson, R., Saleh, P., La, F., Cocu, X., \& Tucka, P. (2014.) Speed Management in Work Zones - The ASAP Project. In Transport Research Arena (TRA) 5th Conference: Transport Solutions from Research to Deployment European Commission Conference of European Directors of Roads (CEDR) European Road Transport Research Advisory Council (ERTRAC) WATERBORNE ${ }^{\text {TP }}$ European Rail Research Advisory Council (ERRAC) Institut Francais des Sciences et Technologies des Transports, de l'Aménagement et des Réseaux (IFSTTAR) Ministère de l'Écologie, du Développement Durable et de l'Énergie.

Vadeby, A., Sörensen, G., Bolling, A., Cocu, X., Saleh, P., Aleksa, M., ... \& Tucka, P. (2016). Towards a European guideline for speed management measures in work zones. Transportation research procedia, 14, 3426-3435.

https://doi.org/10.1016/j.trpro.2016.05.302

Wang, C., Dixon, K., \& Jared, D. (2003). Evaluating speed-reduction strategies for highway work zones. Transportation Research Record: Journal of the Transportation Research Board, (1824), 44-53. https://doi.org/10.3141/1824-06

Żochowska, R. (2014). Improvement of traffic safety in road work zones. Logistyka, 4, 3459-3467.
Paškauskas,

Živilè Sušinskaitè,

Laura Žalimiené

Evaluation

of Speeding

and Behaviour

of Drivers

in Roadwork Zones 